\title{
William D. Davies' Travels to the Welsh Settlements of Iowa in 1886 and 1891
}

\author{
translated and edited by \\ Phillips G. Davies
}

A rare description of Welsh settlers in Iowa is contained in William D. Davies' travel accounts written in 1886 and 1891. As traveling supervisor for a Welsh-language newspaper, Y Drych [The mirror], Davies visited Iowa's Welsh communities to call on local correspondents and to solicit new subscriptions. His observations were printed in the newspaper, which was published then in Utica, New York. Later the pieces were compiled into two books, Llwybrau Bywyd [The paths of life] (Utica, New York: T. J. Griffiths, 1889) and America, a Gwledigaethau Bywyd [America, and the politics of life] (Merthyr Tydfil, Wales: Joseph Williams, 1897).

Davies was born in Carmarthenshire, Wales in 1838. He came to America in 1868 and spent most of his life in Ohio and Pennsylvania. In 1883 he began to work for Y Drych, and until his death in 1900, he traveled extensively around the country visiting the Welsh.

These accounts are of interest for several reasons. They help document the general pattern of Welsh immigration across the United States-generally from New York, Pennsylvania, or Ohio to Illinois and Wisconsin; later to Minnesota and Iowa; and then often farther to the west: to Nebraska, Colorado, and the West Coast. They also emphasize the strong religious feel- 
ings of the Welsh and their quite prejudiced allegiance to one of the two major denominations, the Congregationalists or the Calvinistic Methodists. ${ }^{1}$ Davies' observations also support a major generalization about the Welsh in the Midwest: the coal miners (except for the mine owners) generally suffered here, but the farmers prospered and flourished. Most important, however, these accounts give an insightful view of the Welsh settlements in the state near the end of the last century.

Although they are most often associated with the coal mines and steel mills of Pennsylvania, many Welsh immigrants had settled in Iowa by the late nineteenth century. Census figures for 1900 show that the state contained 3,091 Welsh immigrants and 6,419 children of Welsh immigrants. Iowa ranked sixth in the United States in its Welsh population. As Davies' accounts imply, about half of these immigrants were farmers and half were coal miners. Between strikes and other economic uncertainties, most of the Welsh coal miners seem to have moved away from the state after a short time. ${ }^{2}$ Many descendants of the farmers, however, still remain in the state. There are Welsh-connected church groups today in Lime Springs, at the Old Man's Creek settlement near Iowa City, and in the Long Creek settlement in Louisa County. Williamsburg also contains many Welsh descendants.

For the sake of general interest, the text of Davies' travels has been shortened by nearly one half. The complete translated version is available at the Historical Library, Division of Historical Museum and Archives in Des Moines and at the State Historical Society in Iowa City. This translation reproduces Davies' capitalization, abbreviation, and numeration practices. Words in italics, except Drych, were in English in the original. The headings have been added. The material originally appeared in Articles 19, 22, 23, and 24 of Llwybrau Bywyd and in Chapters 22, 23, and 34 of America, a Gwledigaethau Bywyd.

1. Edward G. Hartman, author of Americans from Wales (1967; reprint ed., New York: Octagon Books, 1978), has defined this church as "Methodist in enthusiasm, Calvinistic in theology, and Presbyterian in church government."

2. In general, coal miners in Iowa were from the northern parts of Europe until 1900, at which time they tended to be replaced by men from southern Europe. 
DECEMBER 1886

LIME SPRING ${ }^{3}$-On Monday, I took the train as far as Lime Spring, Iowa, and on Tuesday, December 14, I went, in the company of John Ll. Jones to the Land of Canaan for the first time ever. ${ }^{4}$ Having reached the house of Hugh Ellis Jones and his mother, I quickly decided that this Canaan is also "flowing with milk and honey." The next day I visited with the great majority of the Welsh and reached the house of John Ll. Jones by dinner time. Because I intended to return to Lime Spring, the family decided to send their daughter with me in the carriage. Blessings on their heads. This world here would be awfully hard and terribly cold, especially for the old bachelors, if it were not for the mercy of the women. By night I reached the house of Richard J. Roberts, the agent for the Drych, who felt badly that he was not able to come with me the next day, but he had work to do because he is extending his barn this year. I also saw Richard Jones, Penllyn, ${ }^{5}$ and his family who are in comfortable circumstances.

I enjoyed a pleasant Sunday at the various religious services. At ten, there was a memorial sermon by the Rev. O. R. Morris for the old faithful deacon, John Jones, who had recently forsaken the earth for the heavens. At two o'clock there was a large and successful Sunday School. In the evening there was an interesting prayer meeting.

FORESTON $^{6}$-Also I had a pleasant time with the Rev. John D. Williams [d. 1887] of Foreston at the fellowship in the afternoon and also in his home. Mr. Williams related the histories of

3. This town is now called Lime Springs. Its name was changed officially in 1949.

4. Evidently Davies was referring to Iowa as "the Land of Canaan."

5. Penllyn [Upper part of the valley] is the name of Jones's farm. Welsh farmers, both in Wales and the United States, often named their farms, partly to add individualization to the limited variety of Welsh surnames.

6. Foreston was once a town in Forest City Township of Howard County. The chapel there was one of the largest in the United States to serve a Welsh congregation. It was built in 1874 and was abandoned in 1924. Material about this town and other abandoned towns comes from various county histories and David C. Mott's Abandoned Towns, Villages, and Post Offices (Council Bluffs, Iowa: J. W. Hoffman and S. L. Purington, 1973). 
the notable Welshmen of the previous age; that is, the famous ones of the Methodist pulpits. Of course, Mr. Williams was in his element there.

On Wednesday, December 22nd, there was an intellectual meeting in the Foreston chapel under the sponsorship of the Union of the Sunday Schools. The meeting was chaired in the morning by the Rev. John C. Jones of Mankato; the organist was Miss Bertha Roberts. The Judges-Singing, the Rev. John C. Jones; the recitations, W. W. Williams of Foreston; the poetry, Rev. John R. Jones (Hendref); ${ }^{7}$ the essays, Rev. Richard Isaac of Lime Spring; the translations, W. Theophilus. We had an interesting meeting because of the various songs by the young people and the children, and there were two choirs singing competitively-one led by Rev. Richard Isaac, and the other by Roger Owen of Foreston, the son of Daniel Owen of Portage City. ${ }^{8}$ The choir of the Rev. Rich'd Isaac obtained a grade of 125 , but the prize was divided between the two in spite of that. In the evening there was a congregational singing meeting under the leadership of the Rev. John C. Jones, at which time we had singing by Miss Bertha L. Roberts, Caradoc Davies, and Owen Jones. Then I spent the night in the company of the Rev. Richard Isaac and his wife, and the next day, after getting a little of the society of Mr. Roberts in Lime Spring and Mr. John $\mathrm{T}$. Jones, in his variety store, I then went on the train to Wisconsin.

\section{Llwybrau, Article 22}

Columbus CitY-From Chicago, I took my way in the Western direction at 11 P.M. on one of the palatial carriages of the Chic. \& Rock Island R. R., and after sleeping comfortably in a reclining chair for about six hours, I found myself crossing the great Mississippi river between Rock Island and Davenport, and then I got off at Columbus Junction. The first whom I met

7. Hendref is Jones's bardic name. Welsh poets often assumed a pseudonym for literary competitions. Several other bardic names appear in these accounts in parentheses after the poets' actual names.

8. The Welsh, said to be one of the first European groups to sing in fourpart harmony, were particularly fond of competitions between choirs. Communities often staged public poetry, singing, and essay competitions, called 
there was the Rev. J. E. Jones, the minister of the Congregationalists at Long Creek.

LoNG C REEK $^{9}-$ I went from there through the mud to call on all the Welsh on the way until I reached the house of the supervisor of the Drych; that is, brother W. V. Davies, who was eager to go with me to see several of the Welsh of the district. Among them was the Rev. T. H. Jones who is a successful and acceptable minister to the Salem Church (Calvinistic Methodist) on the south side of Long Creek. This church has done that which every church ought to make an effort to do; that is, to build a beautiful and convenient house for the use of its minister.

The next day I crossed the river to the territory of the bishop, Richard Hughes [1825-1898], who received me in his house cheerfully. ${ }^{10}$ And although Mrs. Hughes was sick, he went with me willingly to see the Welsh of the district; and, of course, he went with me to see their new and beautiful chapel which has been built since I had been at Long Creek before. We departed from each other in the station of the Chic. \& Rock Island in Clifton. The last person whom I saw there was Mr. Edward J. Davies who has retired from his agricultural labors.

Iowa $C_{\text {ITY }}$ - I was taken away on the carriages to Iowa City, and the first Welshman I saw there was Mr. D. A. Jones, the supervisor of the Drych in the town, who is in the agricultural implement business, etc. Also I had a little society with Wm. Edwards who has sold his farm in the country and come to the town to spend the remainder of his life. Several other respected Welsh citizens include Mr. Griffith, a store keeper, and Daniel Davies, the supervisor of the Gas Co.

eisteddfods. The one reported by Davies presumably would have been quite small, but many choirs of various sizes competed at the eisteddfod at the 1893 Chicago World's Fair.

9. Long Creek was an agricultural district in Columbus Township, Louisa County. Salem Presbyterian church is still active in the district.

10. Hughes was called a bishop because he helped found so many Welsh churches in the Midwest. (The Welsh denominations actually do not have bishops.) Hughes is also the subject of a biography, In Memoriam, Gyfrol Goffa: Y Parch. Richard Hughes [In memoriam, a memorial volume: the Reverend Richard Hughes] (Utica, New York: T. J. Griffiths, 1902). 
Old MAN'S $C_{\text {REEK }}{ }^{11}$ - After traveling one day I reached by night the house of Hugh E. Edwards, the son-in-law of the Rev. Griffith Roberts of Blue Earth Co., Minn. On Sunday morning I went to the Sunday school, and the first one to greet me when I came in was the Rev. D. E. Evans, the minister. At half past four he preached from Joshua $3: 15,16$, a good sermon with scholarly qualities, one which was suitable to and good for one who is a member of the British Philosophical Society, etc. In the evening he preached in English from Math. 6:10- "Thy will be done." I believe that Mr. Evans and the church are getting along with each other fairly well; but it is strange how changeable the world is, and how movable and changeable the children of men are, is it not so! Five years ago, when I was in the district before, the Rev. O. Morfab Jenkins was tending the church and his wife Claudia was well and cheerful by his side, and the three young children were playing about them. But ha! about three years ago the storm came upon this happy and small family. The tender and cheerful mother was broken down by the king of fright, and her remains were buried in the earth next to the chapel and her old sacred home in the area of the West. And now, behold the Rev. D. E. Evans (Trelech) and his happy family who have come to fill the place of the family of the years before. And there is the Rev. Evan Roberts who also has gone the way of all the earth with a beautiful memorial column above his grave.

Then I called at the house of the Rev. D. E. Evans, where he and Mrs. Evans and their children are feeling happy in their new home. . . They continue to study philosophy, science, physics, etc. as well as divinity, and besides the fact that he is writing some things for the chief English-language publications, mostly on points dealing with science and religion, he also promises to give some pieces of the fruits of his labor quickly to the readers of the Drych in the Welsh language.

Then I returned to Iowa City where I did not see a single saloon selling intoxicating liquor, and I saw only one policeman on the streets. Prohibition is working, is it not?

11. This agricultural district was located slightly south and west of Iowa City in Union Township. A Congregational church is still active there. 


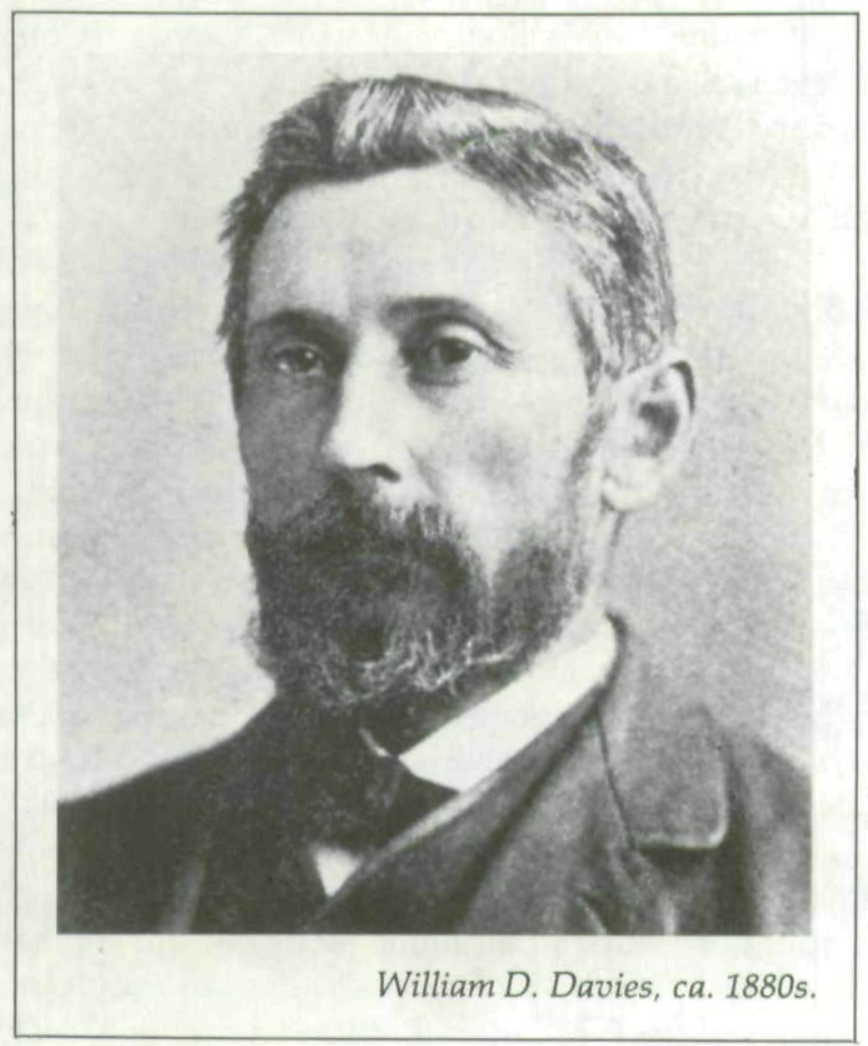

Llwybrau, Article 23

WeLSH PRAIRIE ${ }^{12}$-From there I went to see the Welsh at Welsh Prairie, which I reached by nightfall, and spent some pleasant and witty hours with the old pilgrim, O. W. Edwards.

Williamsburg-The next day I went first of all to Williamsburg and got a good reception from the Rev. Thomas E. Hughes [1844-1921] and his wife. In the evening I had the privilege of going to a temperance meeting which was held under the patronage of the Good Templars. ${ }^{13}$ The meeting was varied by singing, recitation, and speechmaking. There were speeches in English by the three ministers; that is, the Revs. Thomas E.

12. An agricultural district in York Township, Iowa County, slightly east of Williamsburg.

13. The Good Templars was a fraternal order organized for the promotion of temperance with an emphasis on "saving the young, pure and virtuous 
Hughes (Calvinistic Methodist), Henry Davies (Congregational), and William R. Steward (Presbyterian). I think that the churches and ministers are on brotherly and friendly terms with each other, as they ought to be.

On Monday, I went, in the company of the Rev. Thos. E. Hughes, to see some Welsh and went as far as the house of Mr. Edwin Blythin, who had recently received the return of his sight after 35 years of blindness. Surely not without cause was his great joyfulness when he told that he is able to read the Bible and the Drych. Then I returned to the town, and it is not out of place for me to say that Williamsburg has grown a considerable amount since I was here three years ago because the branch of the Chic., Mil. \& St. Paul R. R. now goes through the town. A medicinal spring has been found on the land of $O$. R. Jones, and it is likely to be of benefit to the town. Also coal of excellent quality has been discovered nearby. Thus, I consider that a successful future is in store for Williamsburg, especially if, as in the intention, the county seat is moved from Marengo to this place. Although Iowa is a Prohibition State, the best people of Williamsburg are disappointed that there are some supporters and drinkers of intoxicating liquor here. But one of the most amazing things to me is that I only met one who professes that he is in favor of the Prohibition Party, and that one is Thomas A. Jones, the agent for the Drych. How can it be that the citizens of Williamsburg are going to say good bye to this great reform, and are unwilling to become concerned with this unsatisfactory aspect of the time and let it pass unnoticed?

I went to spend a day in the society of three of the families who were originally from Hyde Park, $\mathrm{Pa}$. and the neighborhood. One of them was the old friend, Thos. J. Williams, the singer, and his family. He and Mrs. Williams and Tommie are looking right happy in their new house and comfortable on their own farm. Henry Jones and his family, formerly of Olyphant, [Pennsylvania] are also in comfortable circumstances in their new home in the country. I also had a little conversation

from ever falling into the snares of the tempter." T. F. Parker, History of the Independent Order of Good Templars (New York: Phillips and Hunt, 1882), 305. 
with Mr. Joseph Freeman and his wife, formerly of Bellevue, $\mathrm{Pa}$.

What CheER-Having stayed for the night in the home of T. J. Williams, I took the train to South Amana, and finally arrived in What Cheer where there are several Welsh. Some of them are famous as citizens, supervisors, literary people, and poets. Among the bosses are two Welshmen, Robert Hughes, the overseer of the coal works; and William Davies, an assistant. Among the poets and literary men are Morgan A. Davies (Athrywyn), Jenkin D. Rees (Gwynlas), and David Jones (Dewi Gwenog). A Welsh woman by the name of Mrs. J. Thomas runs a boarding house near the station of the C. \& R. R. R. in the center of the town. ${ }^{14}$

MuchaCHINOCK ${ }^{15}$-The first Welsh person whom I met in Muchachinock was the Rev. D. R. Lewis (Dewi Mynwy). He complained about the worsening of his health, but after getting something to eat, he seemed much more cheerful and he recited to me some of his poetic works; for instance, "O bury me in the summer," "Behold me, sixty years old," "A memorial poem for the late Rev. J. M. Jones," "The song of the wife of the drunkard," and "The hypocrite." I spent the night in the society of M. G. Thomas (Camarch), who is a noble youth.

ExCELSIOR $^{16}$ - The next day I went to Excelsior, a place where I saw many hospitable and cheerful Welsh. I spent the Sabbath in their midst and heard the Rev. Lloyd Williams preaching in the morning in the Calvinistic Methodist chapel and in the evening in the school house to the union church, as it is called. It is too bad that the Welsh in this place have failed to live in peace and in the same church.

Oskaloosa-From there I went to Oskaloosa, where there are now only a few Welsh. Among them is Llewelyn Lodwick, the successful tea merchant, and Edwin Parry, the regional

14. Davies may have been referring to the Chicago and Rock Island Railroad.

15. Muchachinock, now a ghost town, thrived from 1872 to the early 1890 s. Its population once reached nearly two thousand. It had a post office from 1874 to 1904.

16. Excelsior, located three miles southwest of Oskaloosa, had a post office from 1879 to 1900 . 
secretary of the Knights of Labor, an office which he has held with honor for over three years. ${ }^{17} \mathrm{He}$ also is the overseer of the gas company in the town. Another honorable Welshman in the town is Dr. Bevan, and, of course, there is also Joseph Jones, the wagon maker.

\section{LWybrau, Article 24}

Kirkville-I was on a fairly general visit to the Welsh of Kirkville and I found them to be loving people. I would consider that there are two or three hundred there, all working in, or in connection with the coal mines, except for D. D. Davies who keeps a store there. A Welshman by the name of Richard Rosser is the overseer of the coal works. There is one union church of the Welsh in the place and I believe that they are cooperating peacefully and successfully.

Cleveland, ${ }^{18}$ Lucas-From there I went to Cleveland and Lucas and found that the Welsh there are similar to the Welsh in other locations. But the three Welshmen who were most openhearted and kind to me were Geo. Williams, the agent of the Drych, Mr. Owen C. Roberts (Pererin), and Mr. Ellis Nichols, the policeman at Cleveland, who willingly went with me to see the Welsh of the city.

Des MoINEs-In Des Moines and its neighborhood, and in Sevastopol there are several Welsh families and the Rev. R. W. Hughes of Polk City preaches to them occasionally.

AnGUS $^{19}$-I found the Welsh of Angus with downhearted feelings because nearly all the coal works are idle and more than half of the houses have been vacated, for the time at least. They hope that things will get better there by the end of the summer.

Colfax - There are from 10 to 15 Welsh families in Colfax, living in a fairly pagan condition, that is, from the viewpoint of religious observance. The majority of them belonged to the various denominations before coming to this place. They wish

17. The Knights of Labor was a national federated labor union (which included coal miners) devoted to arbitration.

18. A former town in Lucas County. It was platted in 1878 and had a population of 380 in 1880 .

19. Angus still exists in unincorporated condition in Union Township, Boone County. 
me to say that if some respected minister would call on them when passing through, they would be pleased to have a sermon or two. There are two or three coal works here which are located some four miles outside Colfax, and the trains of the Chic. \& R. I. go there three or four times a day.

I went to see and examine the mineral water which is called the Colfax Springs. It is virtuous and medicinal. There is also a large and convenient summer house there for the use of the people in the summer, and the scenery is pleasant. One sees the carriages of the Chic. \& R. I. passing along the bank of the river below it many times a day. Besides, hundreds come there every summer to seek health and entertainment, and the water is sent by the railroads to various parts of the country, both winter and summer.

RED OAK-I was transported by the carriages of the Chic. $\&$ R. I. to Council Bluffs and Omaha, and from there I went to the Red Oak district to the center of the cheerful and successful Welsh group. However, some changes had taken place since I had been there four years ago. The Calvinistic Methodist church has lost Jones, their old minister, and the Rev. Thomas Miles [1841-1907] has taken his place. But he himself is threatening to leave and to go to Nebraska and to be a farmer. I had the privilege of hearing Mr. Miles preach, and I can only say that he is too good a preacher to go from the pulpit to guide the plow, and to forsake the teaching of morality to feed animals. These circumstances cause me to fear that if things go forward as they are, whatever is the world coming to? The Congregational church has lost its minister, and it is attempting to get the Rev. J. E. Jones of Long Creek to come and be their shepherd. Many have been lost from the settlement in various ways lately, through moving away and death.

\section{America, Chapter 22}

DeCEMBER 1891

Willow CREEK-After visiting with the Welsh of the Lime Spring area in Iowa it was fairly late when Hugh W. Williams asked me to spend that night with him, and he went with me in order to see me safely to the train station at between two and three o'clock in the morning. There I was taken 150 miles to the 
West toward Spencer. After a night of rest, I was taken for some 16 miles across the dry prairie until I was at the home of the cheerful Evan P. Griffiths of Willow Creek. ${ }^{20}$ I was in the chapel of the Welsh Baptists, and in the company of their minister, the Rev. J. T. Lloyd who is successful and acceptable in his new field. They have built a new and beautiful chapel, and they are trying to pay for it before the day of its opening. I noted that the Welsh district of Clay Co. is succeeding in both an agricultural and religious sense. I got a very cheerful welcome throughout the settlement.

\section{America, Chapter 23}

RED OAK-I left Omaha and turned my face toward the settlement at Red Oak. I rested the night with David D. Evans and his family; Mrs. Evans was raised in Tyddyn Meurig, Towyn, Meirionethshire. I saw Mrs. Pritchard who is by herself because her large family has scattered through the mutation of time. There I visited with the old brother, John W. Davies, formerly of Picatonica [Wisconsin], and he seemed content with his destiny among the pigs and the cattle.

Wales-In Wales lives the Rev. H. R. Williams, an acceptable and respected minister of the Calvinistic Methodists, and he is also a successful merchant in the town and the district. D. Davies and his family also live here. He works primarily as a merchant. Here also are Hugh Edwards; the literary man and poet, J. R. Hughes, a blacksmith; and Dr. D. W. Williams, formerly of Youngstown, Ohio, who has come to the town although he had been there before, and has built a new house for the woman whom he intends to marry quickly. He ought to marry, at least, before he becomes much older. I was glad to hear the people in the district praise Dr. Williams as a successful doctor and faithful Christian. He is the son of the late Rev. John W. Williams of Youngstown, Ohio.

The home which was next on my path was the farm house of John G. Jones, the leader of the Body in the district; and with him it is that the visiting travelers of the Methodists are

20. An agricultural district which centered around the Moriah Welsh Baptist chapel, mentioned by Davies, in Douglas Township, Clay County. 
housed. ${ }^{21}$ Of course, he receives me there every time I come from Gomer, Ohio. In the house of Thomas Jones I visited a number of beautiful and cheerful young gentlewomen until I became a bit bashful.

Lucas, Cleveland-In my most recent visit at Lucas and Cleveland, Iowa, I noted a cold and feeble look surrounding the two towns. The coalworking has ended, about half of the houses were empty, many of the Welsh had moved, and the Welsh churches have died. But there were some Welsh remaining there.

Cedar Mines, ${ }^{22}$ Hrteman-From there I was directed to Cedar Mines and Hiteman which are near Albia on the C. B. Q. R. R. There are still coal works in these places, and of course, I went to them to look for the Welsh.

At Cedar there are only some three or four Welsh families, among them the family of the Rev. Wm. H. Thomas of Kansas City, and Wm. Evans, formerly of Cleveland, Ia.

There is a new coal working at Hiteman and there are 12 or 15 Welsh families, the majority of them from Kirkville, and among them are several who receive the Drych. They do not have a Welsh chapel yet, but it is likely that they will be forming a church before too long, and that it will be united with one of the Welsh denominations.

WILlARD, APPANOOSE ${ }^{23}$-Following that I visited at Willard and Appanoose where there are two new coal works within a mile and a half of each other, about ten miles south of Ottumwa on the Chicago, Milwaukee, \& St. Paul R. R. I met with some of my old acquaintances, the majority of them having come lately from an uninhabited Kirkville. Among them was Richard Rosser, the boss; D. G. Davies (Bedwelltydd), the agent for the Drych in Appanoose. . . . There are materials for a good Welsh

21. The Welsh Presbyterian church of Wales was frequently called Hen Gorff [the Old Body]. The term was at times used to refer to its equivalent in America, the Calvinistic Methodists.

22. Cedar Mines is a ghost town three miles west of Albia. It had a post office for some years before 1898. It was in Section 18 of Troy Township. Hiteman still exists.

23. There is no clear evidence about these towns or districts except for Davies' own comment that Willard was ten miles south of Ottumwa. 
union church in this good new place if the coal turns out favorably. But until that time, there is a threat of the people being driven away because of the aspect of the coal.

Welsh Prairie-After that, I visited Welsh Prairie between Williamsburg and Iowa City. The Welsh are becoming sparse in the settlement because of emigration and death, but the Welsh church of the Calvinistic Methodists continues to strive cheerfully and faithfully under the care of the Rev. Edward Joseph who goes about nine miles from Williamsburg every week through all weathers to serve this small church. I had the pleasure of seeing and hearing Mr. Joseph teaching every class in music and the principles of Tonic Sol-fa and I saw at once that he was a successful teacher because all of the class from the old people even down to a girl of five years of age were able to stand up and lead the class with the notes of the various tunes. ${ }^{24}$

WilliamsBuRg-Williamsburg has grown a great deal since the C. M. \& St. P. R. R. has come through the place. The old brother, Thomas A. Jones, the agent for the Drych, went with me to see the Welsh of the town-among them several old friends from Scranton, $\mathrm{Pa}$. and its neighborhood.

Iowa City, Old Man's CReEK-From there Tommie, the son of T. J. Williams, the singer, and I went in his carriage to meet the train at South Amana where I was able to get the train for Iowa City. There I was greeted cheerfully by Daniel Davies, the overseer of the gas company of that city.

After a night of rest, I went to see the dear Welsh of Old Man's Creek once again and I noted that things were going along fairly evenly there without many changes since I had been there previously. I had the privilege of spending Sunday in their midst and hearing the Rev. J. E. Jones deliver a good sermon in English; of course, the strange preacher delivered his sermon also. ${ }^{25}$

LONG CREEK-I then went through Columbus City to see the good Welsh of Long Creek. . . . The Welsh were nearly all

24. As implied by the account, Sol-fa was a method, developed about this time, whereby people who had received no formal musical training could sing parts in hymns rather than just the main musical line.

25. The strange preacher, from evidence elsewhere in the travel accounts, 
cheerful throughout the settlement, and the children of the district are nearly without exception reading and understanding Welsh well. Although this is the oldest Welsh district to the west of the Mississippi, I sold my book very well. This is one of the most successful agricultural districts, and the religious indications, as far as I was able to see, are similar to those of other districts. The Calvinistic Methodists have a good church (Salem) and a strong congregation which fills their chapel and is rich enough to give an honorable salary to a minister and shepherd of the best sort. But somehow they have been unfortunate, and they are eager for a good minister to serve them in a settled manner. There is a young man by the name of Powell, from Wales, who is serving them occasionally, but he is soon going away, I believe. I wish the church would get a minister and his family to fill the beautiful house which is now empty, but which they have provided for him.

And there is a Congregational church at Seion which shows considerable signs of being a hopeful church if they could get a good minister to hearten them in the spirit of the Gospel. They have built a new and beautiful chapel lately and they have paid for it.

At Bethel (Clifton) is the field of work of the Rev. Richard Hughes, "The Bishop of the West," and the Methodists have a pleasant chapel. Their singing is led by Mr. Hughes, lately from Berlin, Wis. I did not get the pleasure of seeing the former, but I found his wife and children cheerful. I had a conversation with H. Richards, the agent for the Drych. He, besides being a good literary man, is also a strong opponent of the business in liquor and tobacco.

MYstic-From there he went with me to the branch between Chicago and Kansas City of the famous Chic. Mil. and St. Paul R. R. to Mystic, a growing mining town about 36 miles to the south-east of Ottumwa. There are not many Welsh there, but the work goes on harmoniously, and the miners earn from 60 to 80 dollars a month. It is also safe and comfortable work

is Davies himself. Although a layman, he, like many important Welshmen of the day, often was invited to speak from the pulpit. Davies' favorite topic was prohibition. 
for those who have skill with the coal pick. As I said previously, the two works are run successfully by the Lodwick brothers, formerly of Youngstown, O., and they have much improved the collieries since I was there before. They have built sheds above and between the collieries and the pouring places for the R. R. cars, etc. There are about 100 working in them and they are so successful that they sell coal to three other companies under the name of Pittsburgh \& Western Fuel Co., Mystic, Iowa. The home business is managed by Llewelyn, and David is caring for the works in the northwest part of Iowa and living in Spencer. William is traveling to sell it in other places. They are succeeding, I believe, and continue to prosper in their business, for they have inherited good characters.

\section{America, Chapter 34}

TEMPLETON-I went for the first time to see the Welsh of the Carroll county district. At first I went to the dwelling place of Samuel Hughes, one of the most skilled farmers in the district, and one of the natives of Caerfyrddinshire. I visited the Rev. William J. Davies whom I had seen years before in Kansas. He too is a successful farmer who takes time to read the Drych. .. . later I came across Ebenezer Jones, formerly of Scranton, $\mathrm{Pa}$. He and his wife are skilled at farming in my opinion. After a night of rest, I visited Joseph Lewis and Thos. Evans, formerly of the Scranton districts. I was able to see that the family was succeeding as farmers. I also saw Henry Thomas and Griffith Thomas, some others also from the district of Scranton, Pa., and after that of Beacon, Iowa where he found his wife.

By Saturday night I reached one of the other families from Scranton, the family of David C. Jones, where I was received with greetings and with memories of the former time. Besides thinking him a success as a farmer, I have reasons to believe that they have succeeded in religion; and it was not unpleasant for me to shake the hand of Arthur, the youngest son who has been one of my co-frequenters of the Band of Hope since the years of his youth. ${ }^{26} \mathrm{I}$ was pleased to understand that he has

26. The Band of Hope was a church-related temperance society for children and youths. 
kept his pledge against intoxicating liquor and tobacco up to the present time to the joy of his parents and the safety and honor of himself.

It was necessary still for me to visit Mrs. Phillips, another faithful one of the Drych, and Thomas Morgan and Ebenezer Evans, and, of course I got the names of the two to receive the Drych in order to be a member of the Welsh world. The Welsh of the district have good farms and I found all of them to be hospitable and loving people. Because I was in their midst over the Sabbath, I attended three preaching meetings; they had two visiting preachers on Temperance there.

DES MoINES-I took myself in the direction of Des Moines, Ia. and met with a benefactor in the Welshman, J. O. Hughes, about whom there had been mention in the papers lately as the most popular letter carrier in Des Moines. He had gotten more votes than any one else, and as a consequence got a free trip to see his old friends in Brookfield, Ohio, and the East. He went with me to visit several of the Welsh of Sevastopol and I got several new names. Thomas Morgan, the tailor, went with me to see several of the businessmen of the town, and among others, L. B. Thomas, Samuel Jones, Thomas Hopkins and his brother; that is, the sons of Thomas Hopkins, one of the old readers of the Drych. Roberts, Johns, and Evans keep restaurants. I saw two Welsh lawyers, D. W. Evans of 95, Clapp Block and, T. J. Evans, R. 35 in the same building. The two are respected Welsh from the district of Williamsburg, Ia. and are going along well in the legal profession. T. J. Evans and another person are running a monthly paper which is called The Rural Northwest, and, of course, they take the Drych. The Welsh of Des Moines speak of establishing a St. Davids Society quickly, and they are eager for some suggestions from someplace to facilitate the start. ${ }^{27}$ Of course, I went to see M. G. Thomas, the supervisor of mining, and he too was looking well and cheerful. Nevertheless I did not have a chance to see all the Welsh in the capital of Iowa, but I was pleased to know that the Welsh are

27. Such societies of Welsh-Americans had been formed in various cities throughout the nation to honor St. David, the patron saint of Wales. The Welsh still celebrate the anniversary of his death on March 1. 
continuing to hold religious services in Welsh under the support of the respected Congregational denomination in Sevastopol, or South Des Moines. There are several Welsh there working in the coal fields.

CARBonADO ${ }^{28}$-From there I went through Oskaloosa to Carbonado. There had been a disturbance between the company and the workers there last summer, and the Welsh have not yet become temperate after losing the argument. I am able to judge that our nation has become angry with God and man and even with themselves, for there were only some eight or nine adults at the Sunday School and the public meeting in the evening. But I hope that they are in better internal spirits than in their outside ones. Robert Roberts and some others are faithful to the chapel in spite of all difficulties. Let the whole group of Welsh increase their moral and religious strength in Carbonado.

BEACON-Although the population of Beacon is growing, I must believe that the Welsh language is now quickly dying there. There is no worship in the Welsh language in the chapel any more.

Grvin ${ }^{29}$ - I remained a night in Givin this time too, despite the fact that many of our nation have become scattered because of the strike. Mrs. Mary R. Jones keeps a full table to serve the workers on the railroad, and there are several other Welsh farming in the neighborhood.

$\mathrm{KAB}^{30}$ - Next I went to see the Welsh at Kab, a new coal works, some four miles north-west of Ottumwa. Several of my old acquaintances from various places are there. For instance, D. D. Jones and his family of Cwm Rhondda, and after that of Kirkville; ... Joseph H. Rees, the musician, and his family of Aberdar [Wales]; Richard Martin and his family, of Kirkville; .... David Morgan of Tredegar, South Wales;.... and Edward Evans and his family of Cleveland, Ia. The town does not yet have any religious services in Welsh.

28. This was a town once located three miles northeast of Oskaloosa.

29. Givin was once located in East Des Moines Township, Mahaska County. It was platted in 1870 .

30. An abandoned town in section 34 of Richland Township, Wapello County. It had a post office from 1891 to 1905. 
Old MAN'S CREEK- . . . I spent the Sabbath again among the saints at Old Man's Creek and heard two good sermons by the minister, the Rev. J. E. Jones, one in Welsh and the other in English, and went to an inspired meeting of the Y. P. C. E. ${ }^{31} \mathrm{On}$ Monday, Owen R. Williams, the agent of the Drych, went with me about the district. There was considerable sickness from the grip there at the time.

Iowa City-Iowa City is one of the most famous cities in the central part of Iowa; that is, in the central part in a comparative way. This was the State Capital when the state was in its infancy before it was moved for some reason to Des Moines, a city more central in the geographical sense. The state authorities have blessed Iowa City with the State University, and thus the city is the sun and the moon to the state yet, because now about 1,200 young people are being cultivated and enlightened in several beneficial branches of learning for the common good. The talented, popular, and generous Daniel Davies, the overseer of the artificial light company of the city, went with me to see the state light plant which is under his management, and I discovered that the service for the educational establishment in six of its large buildings costs something like 52,000 dollars a year. Thus one sees that the institution is the fountain of life in various ways for Iowa City. The geological and zoological museum in the town has an excellent and varied collection. There also is a new and beautiful Y. M. C. A. building which cost 40,000 dollars. The population of the town is between 8,000 and 10,000 , but there are only a few Welsh living in it.

31. The Young Peoples' Christian Endeavor Society was another churchrelated youth group. 
Copyright of Annals of Iowa is the property of State of Iowa, by \& through the State Historical Society of Iowa and its content may not be copied or emailed to multiple sites or posted to a listserv without the copyright holder's express written permission. However, users may print, download, or email articles for individual use. 